\title{
Awareness and adoption levels of improved smoking oven among fish processors in Lagos Lagoon, Nigeria
}

\author{
O. T. ALABI*, O. J. OLAOYE, F. O. A. GEORGE, A. A. ADEOLA, J. O. ALABI, \& W. G. \\ OJEBIYI \\ (O.T.A \& F.O.A.G: Department of Aquaculture and Fisheries Management,; O.J.O:
} Agricultural Media Resources and Extension Centre (AMREC),; A.A.A: Institute of Food Security, Environmental Resources and Agricultural Research (IFSERAR), W.G.O.: Department of Agricultural Extension and Rural Development, Federal University of Agriculture, Abeokuta, P.M.B 2240, Ogun State, Nigeria,; O.T.A \& J.O.A.: Favour and Mercy Agricultural Production and Training Centre, Abeokuta, Ogun State, Nigeria)

*Corresponding author's email: queenomotayo@gmail.com

\begin{abstract}
This paper investigated awareness and adoption levels of improved smoking oven among fish processors in four fishing communities along Lagos Lagoon, Nigeria. Multi-stage sampling procedure was used to select 153 respondents who were engaged in fish smoking. Data collected using structured interview guides were subjected to descriptive and inferential analyses. Results revealed that majority of the respondents were young, married women with average fish smoking experience of 22.6 years. Majority (90.8\%) of them were solely engaged in fish smoking while $9.2 \%$ combined fish smoking with other income-generating activities. All the processors used traditional smoking oven (drum, box and mud ovens). More than $66.0 \%$ of the fish processors were not aware of improved fish smoking equipment. Lack of awareness, inadequate access to the technologies, low relative advantage and lack of maintenance services and high cost of procurement were responsible for low adoption levels of improved smoking oven. Irregular visits of extension agents to the study area had negative impact on the adoption of improved traditional smoking ovens. Proper dissemination of innovations developed on improved fish processing equipment to the active fish processors in Lagos State using available communication channels is hereby advocated.
\end{abstract}

Keywords: Lagos Lagoon; fish processing; smoking oven; extension service; adoption Original scientific paper. Received 10 Mar 2020; revised 27 Oct 2020

\section{Introduction}

The global demand for fish as food is increasing not only due to upsurge in population rise but also because it is known as a safe source of animal protein that is widely available and affordable for all regardless of the socioeconomic status (Olaoye et al., 2015). Also, the amino acid profile, low cholesterol content, numerous vitamin and mineral contents as well as fatty acid profile makes fish stand out among all the sources of animal protein (Olaoye et al., 2015). Fish is usually consumed in its preserved form than as fresh (NerquayeTetteh et al., 2002). Of all the processing

Ghana Jnl Agric. Sci. 55 (2), $39-58$

GJAS is an Open Access Journal and distributed under the terms of the Creative Commons (CC) License [CC BY 4.0] 
methods often employed (either singly or in combination) by artisanal fish processors, fish smoking (curing process) remains the most common and cheapest processing method in most developing countries including Nigeria, Ghana, Cote d'Ivoire, to mention a few (George et al., 2014; Olaoye et al., 2015; Sakyi et al., 2019).

Smoking preserves fish by fish cooking, drying, and depositing natural wood-smoke chemicals like tars, phenols and aldehydes all of which have powerful bactericidal action which prevents the growth of other micro-organisms on the flesh of the fish (Garrow \& James, 1993; Sakyi et al., 2019). As noted by Asiedu et al. (2018), smoked fish is consumed by all and sundry due to its better taste, comparably higher nutrient quality and availability at various markets (domestic rural and urban markets, sub-regional and international markets). Traditional processing of fish remains a pivotal means of making cured fish available to Nigerians and many other Africans. This is probably because fish processing activity is domiciled in the artisanal fishery sectors where majority of fish processors employ the use of traditional equipment (Inoni \& Oyaide, 2007; Sakyi et al., 2019). Empirical evidence has shown that majority of smoked fish processors in Nigeria employed traditional techniques and processing equipment that have been in existence for several decades such as cylindrical metal or oil-drum oven (full or half drum), mud oven, box oven, and brick kiln (Davies et al., 2008; George et al., 2014; Olaoye et al., 2015; Odediran \& Ojebiyi, 2017).

However, the major shortcoming of traditional smoking ovens hinged on the poor-quality smoked fish as evidenced by higher polycyclic aromatic hydrocarbons (PAHs) concentration which is of safety, public health concerns and inefficient due to excess fuel consumption. Previous studies by Silva et al. (2011) and Ake Assi et al. (2014) established a positive link between the use of the traditional smoking oven and higher PAHs concentration in smoked fish. In view of this, interventions aimed at addressing this issue include developing improved smoking ovens and intensifying efforts towards the adoption of improved fish processing techniques. Improved smoking oven such as Chorkor oven and smoking kilns has several superior advantages over traditional smoking oven which include high-quality smoked fish products, higher productivity, large smoking capacity, shorter smoking duration, better fuel-use efficiency, and lower PAHs concentration in smoked fish. It also reduces fish processors' exposure to health hazards and injuries (Sakyi et al., 2019). However, the existing information reflects low level of adoption of improved fish processing technologies among smoked fish processors in some parts of Lagos State, Nigeria (Odediran \& Ojebiyi, 2017). This is worrisome due to its implications on food security and food safety. Therefore, it is prudent to assess the awareness and adoption level of improved traditional fish smoking oven among fish processors in Lagos Lagoon. Arising from the above, the objective of this study was to investigate the adoption level of improved fish smoking oven among fish processors in Lagos State; and the impact of fisheries extension services on the adoption level of improved traditional fish smoking oven in the study area. The following hypotheses were tested: i). Socio-economic characteristics of fish processors have no significant impact on the adoption of improved traditional fish smoking oven, and ii). The adoption of improved traditional fish smoking oven did not depend on the effectiveness of extension services. 


\section{Materials and Methods}

Description of the study area

The research was conducted in Lagos State, located in the South-Western part of Nigeria on the narrow coastal plain of the Bight of Benin (Olaoye et al., 2016). Lagos Lagoon is a tropical, coastal estuary located in the heart of Lagos metropolis and is the largest of the four lagoon systems in the state. It cuts across the southern part of the metropolis, connecting to the Atlantic Ocean by Commodore Channel in the west and south and Lekki Lagoon in the east (Okusipe, 2004). The lagoon is located between longitudes $3^{\circ} 23^{\prime}$ and $3^{\circ} 40^{\prime} \mathrm{E}$, and latitudes $6^{\circ} 22^{\prime}$ and $6^{\circ} 38^{\prime} \mathrm{N}$ (Phillips et al., 2012). It measures over $50 \mathrm{~km}$ and varies in width from 3 to $13 \mathrm{~km}$ at its widest point thus covering an area and perimeter of 6354.708 $\mathrm{km}^{2}$ and $285 \mathrm{~km}$, respectively. The Lagos Lagoon consists of three main segments, viz; Lagos Harbour, the Metropolitan end and Epe Division segments. The lagoon is shallow in most places, usually 2-4 $\mathrm{m}$ deep, except at the entrance at the Commodore channel where it is $10 \mathrm{~m}$ deep (Okusipe, 2004). The map of Lagos Lagoon showing the study area is presented in Fig. 1. Study area co-ordinates were taken using Global Positioning System (GPS) software while the map was drawn using ArcGIS Software (ESRI Inc., Redlands, California, United States of America).

Study design, sampling procedure and sample size determination

The study adopted the multistage sampling technique which comprises both the non-probability (purposive) and probability (simple random) sampling techniques. Four fishing communities along Lagos lagoon were purposively selected based on high intensity of fishing and fish processing. The purposively selected communities were Epe,
Ejinrin, Agbowa-Ikosi, and Bayeku. Extension personnel and fish processors association leader of each location were consulted to know the total number of registered fish processors. Thereafter, $70.0 \%$ of registered fish processors were selected from each community using a simple random sampling technique which resulted in a sample size of 153 fish processors out of 218 registered fish processors.

Data collection instruments, pretesting and data collection

The instrument used for the gathering of primary data was a validated and pre-tested interview guide. The interview guide was divided into four with Section A containing the socio-economic characteristics of fish processors in the study area; Section B focused on the fish smoking practices and types of smoking oven used; Section $\mathrm{C}$ focused on the awareness and adoption level of improved traditional fish smoking oven, and Section D looked into access to fishery extension service. A semi-structured interview guide was administered to the selected smoked fish processors in order to assess the awareness and adoption level of improved fish smoking oven. Level of awareness depicts the proportion of fish processors who knew that an innovation (improved fish smoking ovens) exists which has potential benefits and practical relevance to enhance fish smoking activities (Özçatalbaş, 2014). Meanwhile, adoption level refers to the degree of acceptance of such an innovation (Bolorunduro \& Adesehinwa, 2007). Level of awareness and adoption were categorized as low or high if lower or higher than $50 \%$ of respondents, respectively. The interview schedule is structured in such a way to consists of both open and closed-ended questions. The open-ended questions allow the respondent to express their own opinions about specific 
situations in order to fulfill the specific objectives of the study. The interview guide used for the data collection was found to be valid and reliable through face and content validity, as well as the test-retest method, respectively.

\section{Data analysis}

Data generated from the interview guide were coded appropriately in Microsoft Excel. They were analyzed using descriptive statistics such as frequency distribution, percentage, and meanwhile the tested hypotheses were analyzed with Pearson Product Moment Correlation and multiple linear regression analysis using Statistical Package for Social Sciences (SPSS 20.0 version; SPSS 2017).

\section{Results and Discussion}

Socio-economic characteristics of fish processors in Lagos Lagoon

The distribution of fish processors surveyed in the four fishing communities along Lagos Lagoon with respect to their socioeconomic characteristics is presented in Table 1. Almost all (99.4\%) of the processors were female. This is in congruence with previous assertions that female are mostly involved in the processing and marketing of the fish caught in the artisanal fishery while male-dominated the fishing activities, particularly in Africa (Inoni \& Oyaide, 2007; Okwu \& Acheneje, 2011; Ake Assi et al. 2014; Shettima et al., 2014; Sakyi et al., 2019). In agreement, George et al. (2014) found that $97.9 \%$ of the fish processors in Ibeju-Lekki Local Government of Lagos State were women. Age is another important socioeconomic characteristic in the fisheries sector as it affects productivity, output and adoption of innovation (Olaoye et al., 2016). Majority (77.8\%) of the respondents are able-bodied and agile young women who were below the age of 50 years (mean age $=41 \pm$ 14 years) thereby possess the physical strength to sustain rigorous and arduous tasks required in fish processing. Previous studies have also shown that most people that are engaged in fishery-related activities were in their youthful, productive and economic active age, usually between the ages of 20 and 50 years, simply because such activities require much energy (Ake Assi et al. 2014; George et al., 2014; Ashley-Dejo et al. 2017; Odediran \& Ojebiyi, 2017). This explains why Bolorunduro \& Adesehinwa (2007) considered this age bracket as the economically active age group which would be more inclined to adoption of innovations that could enhance productivity and increase their income margin.

Majority $(91.0 \%)$ of the respondents were married with dominant household size of six people per household. This implies that the fish processors were people of financial responsibility who may depend on the income from their business as a means of livelihood to cater for the family needs (Odediran \& Ojebiyi, 2017). It is a common practice that family members also participate actively in fish processing and marketing activities thereby constituting the labour force, especially if they are adults and not dependents. Household size is often influenced by the educational status, locality, religion, mother's working status and family income level and/or wealth index. The mean household size in the study area is similar to the findings of Odediran and Ojebiyi (2017) who reported an averagely six members per household among fish processors in selected fishing communities of Lagos State. Bolorunduro and Adesehinwa (2007) and Ashley-Dejo et al. (2017) also reported an average of six persons per household among fisherfolks (fishermen, fish processors and fish 
farmers) in Lagos and Rivers States as well as catfish farmers in Oyo State, respectively.

Respondents' educational status in this study revealed high level of illiteracy as nearly half of the respondents $(49.7 \%)$ had no schooling (non-formal education) while $29.4 \%$ had primary school education, and $19.6 \%$ had post-primary school education. This aligns with the works of Odediran and Ojebiyi (2017) who found that close to half $(48.2 \%)$ of the fish processors in Lagos State had no formal education. Kolawole et al. (2010) also reported that majority of the fish processors in Southwestern Nigeria had only primary-level education. A study by Ake Assi et al. (2014) noted that $59 \%$ of fish smokers in Abidjan, Cote d'Ivoire are illiterate. This probably would not only affect their living standards but could also have adverse effects on the ease of comprehension and adoption of introduced improved technologies and innovative practices. The fundamental role of education in every aspect of life and for successful business enterprise cannot be belittled as it provides a better chance for awareness, persuasiveness, reception and applicability of new or improved innovations for optimum productivity (Özçatalbaş, 2014). Adeyeye et al. (2015) had also noted that level of education is positively related to employment and income level which inescapably influences access to household amenities and facilities, including those related to biosecurity and hygienic measures together with environmental health during fish processing.

The study further revealed that $29.4 \%$ of the respondents had 11-20 years of fish smoking experience, $22.2 \%$ had 21 and 30 years of experience while few $(8.5 \%)$ had more than 40 years of working experience. Fish smoking experience depicts the number of years that the fish processors had spent in this business. Longer years of experience are usually correlated with better performance. In this present study, the mean fish smoking experience (22.6 years) which indicated that most of the sampled fish processors would have had sufficient mastery of fish processing skills, and could understand the business trends in terms of seasonal availability of harvested fish, shift in operation conditions, as well as price fluctuation of inputs and fish products which could inform their decision making. This result is in accordance with the report of Odediran and Ojebiyi (2017) who observed an average fish processing experience of 21.48 years and opined that they will be able to decide logically and rationally whether to adopt a technology or not based on their wealth of experience on the existing technologies vis-à-vis the newly introduced ones.

Almost all (98.0\%) of the fish processors were members of fish processors association while only $3.3 \%$ belonged to Cooperative society. Social associations help their members to pool their resources thereby having access to credit facilities (Olaoye et al. 2012). It also provides a better platform to have insights into critical fish smoking issues such as price control, sharing of fish and/or smoking oven whenever there is abundance or scarcity. The welfare needs of registered members are also being attended to. One of the fundamental problems faced by fish processors is inadequate financial resources and/or unavailability of credits or loans to expand their business (Sayki et al., 2019). Meanwhile, membership of social groups could facilitate the fish processors' access to credit facilities from the financial institutions as intervention agencies would prefer to assist groups than individuals (Olaoye et al. 2012). Information dissemination to raise awareness on improved technologies or innovations could be more 
effective as extension workers could reach more people through their respective social organizations especially the fish processors' associations. Due to the influence of peer pressure, fish processors are likely to adopt new technologies because their colleagues adopted such technologies (Ashley-Dejo et al. 2017). Low subscription to cooperative society by fish processors in this study could be attributed to their low level of education as well as lack of awareness and interest.

\section{Fish processing characteristics of the fish processors in Lagos Lagoon}

Table 2 shows the fish processing characteristics of the fish processors in Lagos lagoon. The results revealed that majority $(90.8 \%)$ of the fish processors were exclusively into fish processing on a full-time basis while $8.5 \%$ and $0.7 \%$ were part-time and occasional fish processors, respectively. This is an indication that fish processing is the major means of livelihood as well as the main source of income of the respondents. This is likely the major drive because the fishery-related enterprise had been reported to be profitable (Okeowo et al., 2015; Ashley-Dejo et al., 2017). Some respondents also combined fish processing with trading $(2.6 \%)$, civil service (3.9\%), fishing $(0.7 \%)$ and vocational jobs like hairdressing and fashion designing (1.9\%). This suggests that revenue generated from such occupations can serve as an additional source of income. However, fish processors who had no other occupation apart from fish smoking might be vulnerable to economic loss should there be a problem as a result of seasonality and natural disaster. Furthermore, almost all (97.4\%) of the respondents went into fish processing primarily to make profit while others ventured into the business for household consumption $(15.0 \%)$ and increase in streams of income $(5.8 \%)$.

Majority $(88.2 \%)$ of respondents processed smoke fish every day while $11.1 \%$ processed fish between four and six times a week. Also, close to half $(47.7 \%)$ of the respondents often process less than $100 \mathrm{~kg}$ of fish per time while $39.9 \%$ processed between 101 and 200 $\mathrm{kg}$ of fish. This implies that the fish processors are small-scale business owners. The scale of production, the commercial value of smoked fish products, and marketing channels (direct sales to final consumers or through middlemen) could influence the fish processors' revenue and gross margin. Respondents' income level shows that most $(45.7 \%)$ of the respondents had monthly income of $\$ 31,000-60,000$ while $32.0 \%$ earned at most $\$ 30,000$ per month, 16.3\% earned $\$ 61,000$ - 90,000, and $5.9 \%$ earned more than $\$ 90,000$. The average monthly income from fish processing activities was $¥ 48,274.51 \mathrm{~K}$. This could be an indication that the fish processors were earning relatively higher income than most civil servants in Nigeria where state governments are struggling to agree on a minimum wage of $\$ 30,000$ for the workers. The amounts earned per month could be the major driving force that motivated even youths into the enterprise. This agrees with the findings of Olaoye et al. (2013) and AshleyDejo et al. (2017) who reported that artisanal fisher folks and fish farmers were motivated by the revenue generated from the enterprise. Undoubtedly, income level is positively linked with the financial status of individual and whoever earns higher income could have access to better living standards and health care than those who have lower revenue. Likewise, higher income could enhance the opportunity to adopt innovations due to higher purchasing power (Özçatalbaş, 2014). 


\section{Types of fish smoking oven used}

From this study, more than half $(54.2 \%)$ of the processors used drum oven as smoker, $45.7 \%$ used box oven while $39.2 \%$ used mud oven (Fig. 2). This is an indication that drum and box ovens were the most commonly used smoking ovens in the study area. Previous studies also revealed that majority of fish processors used traditional smoking oven (Davies et al., 2008; George et al., 2014; Adeyeye et al., 2015). A study by Davies et al. (2008) found that the use of drum and mud ovens were prevalent among fish processors in Rivers State, Nigeria. In the same vein, recent studies reported drum and mud ovens as the commonly used smoking ovens by fish processors in Abidjan, Côte d'Ivoire (Ake Assi et al., 2014) and Lagos State, Nigeria (Adeyeye et al., 2015; Odediran \& Ojebiyi, 2017). On the contrary, George et al. (2014) reported galvanized iron sheet oven as the prevailing processing equipment in IbejuLekki LGA, Nigeria. Meanwhile, Sakyi et al. (2019) reported that fish processors in Ghana employed improved types of conventional fish smoking ovens, chorker smokers, oil drums and upgraded smoking techniques.

\section{Awareness and adoption levels of improved traditional smoking oven}

Findings presented in Table 3 indicate that the level of awareness among the fish processors was low with regards to the improved fish smoking ovens as more than two-thirds of the respondents were not aware of the improved fish smoking equipment. Only $34.0 \%$ of the fish processors were aware of improved mud oven while 15.7, 15.7 and $20.3 \%$ were aware of improved box oven, chorkor oven and smoking kiln, respectively. The low level of awareness of improved processing equipment is worrisome and could be an indication of inadequate diffusion of improved fish processing technologies by the extension agents to the fish processors in the surveyed fishing communities. It is well known that having knowledge or information (awareness) is the foremost and critical stage in the five-step innovation adoption process followed by interest, evaluation, trial, and adoption (Özçatalbaş, 2014). In agreement, Odediran and Ojebiyi (2017) opined that high level of awareness is a key requirement for technologies to be adopted. Therefore, this situation requires that fish processors be reached with available innovations to enable them to utilize such for increased productivity and better living standards. We found that awareness of improved fish smoking oven was considerably higher among smoked fish processors in Epe (data not shown). This implies that Epe has received much attention of the extension agencies, research institutes and/or non-governmental bodies in terms of information dissemination through several channels when compared with other study locations. This assertion was confirmed through several reported studies on fishing activities and fish processing in Epe, Lagos State (Ajagbe et al., 2012; Adeyeye et al., 2015; Okeowo et al., 2015; Odediran \& Ojebiyi, 2017).

Table 3 shows the adoption level of each improved traditional smoking oven. More than $60 \%$ of the respondents who were aware of improved traditional smoking oven did not try to use it. Furthermore, $38.5 \%$ of the fish processors tried the usage of improved mud oven while $32.7 \%$ of them adopted but discontinued its usage with time. Meanwhile, $5.8 \%$ of them rejected the innovation after few moments of trial. Regarding chorkor oven, only $4.2 \%$ of respondents tried and adopted the innovation 
but it was discontinued. Consequent to the low level of awareness of improved processing equipment, the adoption rate of the different improved fish smoking ovens was also low. This agrees with the findings of Bolorunduro et al. (2005) who reported low adoption level of improved smoking kilns (Altona, Chorkor, Burkinabe and Watanabe) among smoked fish processors in Northwestern Nigeria. Odediran and Ojebiyi (2017) also reported low adoption of charcoal fish smoking kiln among fish processors in Lagos State.

\section{Reasons for non-adoption and/or discontinuance of improved traditional smoking ovens}

The results on the reasons for nonadoption and/or discontinuance of improved traditional smoking oven are presented in Table 4. It reveals that fish processors indicated lack of awareness of the technologies (66.0\%) and lack of access to the technologies (31.3\%) were the major reasons for their non-adoption of improved traditional smoking ovens. This is because most of the technologies were presented to fish processors, especially their Union Leaders, during workshops without providing means for the fish processors to access the technologies for their use. This might suggest inadequate information dissemination and knowledge sharing by extension personnel and/or among fish processors. Other important reasons, based on the responses of significant proportion of the fish processors include low carrying capacity due to limited number of fixed wire mesh (18.9\%), high cost of procuring modern smoking kiln (15.6\%), difficulty in turning fish during smoking (11.1\%), and low relative advantage $(5.23 \%)$. This agrees with the established fact that innovation to be adopted should be of superior advantage and more economic-efficient compared to the technology that will be replaced (Rogers, 2003; Wisdom et al., 2014). Other constraints noted by the respondents are lack of repair and maintenance service $(4.58 \%)$, and lack of interest in the technologies $(1.96 \%)$.

Symbolic rejectors, who based their decision on the dissatisfaction expressed by their peers, confirmed the impact of social influence from interpersonal sources (family, friends, peers and colleagues) as a major determinant in the adoption of innovative technology, primarily in stages of trial and final adoption. This implies that socioeconomic, political, cultural and technological factors play significant role in the adoption of innovations. Meanwhile, for the adoption of fish processing technologies to take place, it is expected that innovations or improved technologies that do not receive high awareness should be re-introduced and popularized and that the strengths and possible opportunities of adopting such technologies should be duly demonstrated (Olaoye et al., 2016). Therefore, proper dissemination which ensures that the innovations developed on improved fish processing equipment and techniques reach the active fish processors in Lagos State should be done by extension agents.

Fisheries extension variables associated with fish processing in Lagos Lagoon

Table 5 shows the fisheries extension variables associated with fish processing in the study area. Almost all (99.4\%) of the fish processors were aware of fisheries extension services within the study area. More than half $(53.9 \%)$ of the fish processors became aware of extension services through extension visits while $46.1 \%$ became aware through fellow fish processors. More than half $(53.5 \%)$ of the respondents have been visited at one time or the other. To worsen the situation, most $(84.2 \%)$ 
of the visited fish processors were visited on irregular basis. This implies inadequate and untimely access to information. This confirms the reason for low level of awareness and adoption of improved technologies by the fish processors. It is generally believed that adoption of innovation begins with awareness which occurs when an individual knows that such an idea exists (Wisdom et al., 2014). Beyond this, however, the time required to complete innovation adoption process varies according to the characteristic of innovation, the way it is presented, and the characteristics of individuals (Özçatalbaş, 2014). Therefore, extension workers are expected to be consistent and persistent in the dissemination and demonstration activities in order to hasten the adoption of technologies being introduced.

Regarding the period of fish processors' contact with extension agents, most of them were visited for the first time $(45.1 \%)$ and the last time $(59.8 \%)$ between the years 2010-2018. Noteworthy is the fact that extension agents in Nigeria are very dutiful owing to the high intensity of their extension services as evident in higher level of awareness by stakeholders in fishery sectors (Ogunremi et al., 2016; Olaoye et al., 2016). However, the likely reasons for differences in the period of visit by extension workers could include proximity of fish processing centres or communities to extension offices, inadequate number of extension workers, inadequate funding and other logistics.

\section{Perceived effectiveness of extension services by fish processors in Lagos Lagoon}

Perceived effectiveness of extension services among fish processors is presented in Table 6. Most (75.1\%) of the respondents had not received any form of training on fish processing by the extension workers. Various aspects of fish processing covered during the training attended include the use of improved mud oven (63.2\%), modern smoking kiln (23.7\%), and improved smoking techniques (13.2\%). Some $(27.5 \%)$ of the respondents asserted that the training programmes were organized by extension workers through organizations such as FADAMA, Advancing Capacity to support Climate Change Adaptation (ACCCA), and All Farmers Association (AFAN). There is high degree of variation in respondents' participation in each of the training programmes organized. Results show that $17.7 \%$ of the respondents usually participate in the training programmes on a regular basis while about $19.0 \%$ attend occasionally. Effectiveness and efficiency of the extension services provided by extension workers on information sharing and demonstration of improved fish processing technologies were assessed by fish processors majorly as poor $(42.5 \%)$, fair $(30.1 \%)$ and $\operatorname{good}(15.0 \%)$.

Correlation analysis of the socio-economic characteristics, fish smoking activities and adoption of improved smoking ovens

In this study, certain socio-economic factors of respondents (variables) were tested on the fish processing activities and adoption of improved traditional smoking oven. For all significant variables, the correlation coefficients ' $r$ ' was very weak $(r<0.4)$ showing a weak relationship among variables. Results of Pearson Product Moment Correlation (PPMC) analysis as presented in Table 7 showed that significant association exist between mode of fish smoking operations and gender $(r=0.23, P$ $<0.01)$, educational level $(r=0.25, P<0.01)$, and household size $(r=0.21, P<0.05)$. The implication is that women with higher literacy and family size are more likely to smoke fish on a full-time basis. The significant inverse 
correlation of frequency of fish smoking to the age of respondents $(r=-0.27, P<0.01)$ indicates that productivity and output would diminish as age impresses due to the reduction in physical strength and energy required to carry out tedious tasks in fish processing (Olaoye et al., 2012).

The negative relationship between frequency of fish smoking and gender of respondents $(r=-0.30, P<0.01)$ confirms the assertion that fish smoking in artisanal fishery is the exclusive responsibility of women, and that frequency of fish smoking would decrease if more men are involved in fish smoking in this study area. More so, an inverse correlation of frequency of fish smoking to marital status $(r=-0.17, P<0.05)$ and household size $(r=$ -0.18, $P<0.05)$ implies that married women with large family size would require more time to discharge the family responsibilities. Olaoye et al. (2016) and Odediran and Ojebiyi, (2017) reported that marriage was highly cherished by fisher folks in Southwest Nigeria, thereby always express their commitment to the obligations conferred on them by marriage. The study also found that the frequency of fish smoking was inversely correlated with years of experience in fish smoking $(r=-0.29, P$ $<0.01)$. This implies that older smoked fish processors would employ their expertise to ensure a known quantity of fish is smoked in fewer batches.

There was statistically significant inverse correlation between adoption of improved smoking oven and age $(r=-0.32$, $P<0.01)$, marital status $(r=-0.22, P<0.01)$, as well as fish smoking experience $(r=-0.20$, $P<0.05)$. This points out that there is the likelihood that adoption level would decrease among older, married smoked fish processors who might not be able to procure or construct the improved ovens. This probably could be due to their financial responsibility as a larger share of their income might be used to cater for the family needs. In agreement, Odediran and Ojebiyi (2017) had noted that fish processors who are breadwinners of their households expend more of their income to meet the household needs.

Regression analysis for the determinant of adoption of improved fish smoking oven

Table 8 revealed that adoption of improved smoking oven by smoked fish processors is significantly predicted by their age $(\beta=-0.658, P<0.001)$, years of fish smoking experience $(\beta=0.444, P<0.01)$, frequency of fish smoking $(\beta=-0.163, P<$ $0.05)$, extension agent visit $(\beta=0.338, P<$ $0.001)$, training on fish smoking $(\beta=0.285, P$ $<0.01)$ and effectiveness of extension services $(\beta=-0.232, P<0.05)$. The $\mathrm{R}^{2}$ of 0.366 for the regression analysis model with $\mathrm{F}$-value of 6.638 and $0.1 \%$ significant level implies that $36.6 \%$ of the variability in the smoked fish processors' adoption of improved smoking oven is explained by their age, fish processing activities, and effectiveness of extension services. The negative relationship between age and adoption of improved smoking oven implies that as age increases the smoked fish processors become less productive as per $a$ priori expectation. Thus, they might not be enticed to adopt any improved technologies. Therefore, educated young people should be encouraged to be involved in fish processing so as to promote the adoption of improved technologies.

Fish smoking experience had a positive influence on the adoption of improved smoking oven which could be due to sufficient mastery of fish processing skills and better resource-use efficiency as years of experience increase. This is in congruence with the finding of Bolorunduro 
et al. (2005) and Odediran and Ojebiyi (2017) who stated that the more the fish smoking experience, the higher the tendency for the adoption of fish processing technologies. The positive coefficient of improved smoking oven adoption and extension visits, training on fish smoking as well as effectiveness of extension services was the a priori expectation which indicates that with more visits and effective information dissemination on modern fish smoking technologies, there is a higher prospect for the adoption of improved techniques or innovations among smoked fish processors. This is strongly supported by Bolorunduro et al. (2005) who reported a significant correlation between extension contacts and adoption of improved smoking oven. Summarily, this study found that respondents' age, marital status, years of experience in the fish processing business, extension visits, training on fish smoking and effectiveness of extension services would influence the adoption of improved traditional fish smoking oven among fish processors in Lagos State. Based on the findings of this study, the null hypotheses tested were rejected. This implies that adoption of improved traditional fish smoking oven depends on the socio-economic characteristics of fish processors and the effectiveness of fisheries extension services.

\section{Conclusions and Recommendations}

The study revealed that smoked fish processors were mostly women within the economically active age with nearly half of them having no formal education and majority of them being married. All the processors used traditional smoking oven such as drum oven, box oven and mud oven. Most of the fish processors were not aware of improved fish smoking equipment. The adoption level of improved fish smoking ovens was low with its usage being discontinued over time. Irregular visits of extension agents to the study area had negative impact on the adoption of improved traditional smoking ovens. The null hypotheses tested were rejected because socio-economic characteristics and access to extension services influenced the adoption of improved smoking oven.

Extension agents should ensure proper dissemination of innovations developed on improved fish processing equipment and techniques to the active fish processors in Lagos State. More so, all concerned stakeholders, particularly Lagos State Agricultural Development Authority (LASADA), should endeavor to extend their coverage area to other locations, especially Agbowa-Ikosi, Bayeku and Ejinrin using as many channels as possible. Fish processors should be empowered financially by the government and other funding bodies so that they can procure (or acquire) the improved smoking oven such as chorkor oven, smoking kiln or FAO-Thiaroye Oven. Also, modern fish processing centres should be constructed in fishing communities along Lagos Lagoon to facilitate processors' access to the technologies. Educated youths should be encouraged to be involved in fish processing so as to promote the adoption of improved technologies.

\section{REFERENCES}

Adeyeye, S.A.O., Oyewole, O.B., Obadina, A.O., Omemu, A.M., Oyedele, H.A. \& Adeogun, S.O. (2015) Socio-economic characteristics of traditional fish processors in Lagos State, Nigeria. International Journal of Aquaculture $5(37), 1-6$.

Ajagbe, F.E., Osibona, A.O. \& Otitoloju. A.A. (2012) Diversity of the edible fishes of the Lagos Lagoon, Nigeria and the public health 
concerns based on their Lead $(\mathrm{Pb})$ content. International Journal of Fisheries and Aquaculture 2 (3), 55 - 62.

Ake Assi Y., Sess A., Anon N., Oga S., Kouame P., Bonfoh B. \& Biego, G.H.M. (2014) Description of risk factors in the formation of hydrocarbons during the traditional fish smoking in Abidjan. Journal of Health Sciences 2, $222-234$.

Ashley-Dejo, S.S., Olaoye, O.J. \& Adelaja, O.A. (2017) Comparative evaluation of economic benefits of adopters and non-adopters of improved fish production technologies in Oyo State, Nigeria. Nigerian Journal of Animal Production 44 (2), 223 - 229.

Asiedu, B., Failler, P., \& Beygens, Y. (2018) Ensuring food security: an analysis of the industrial smoking fishery sector of Ghana. Agriculture \& Food Security 7, $1-11$.

Bolorunduro, P.I. \& Adesehinwa, A.O.K. (2007) Adoption levels of improved fisheries technologies and impacts of extension services on fisher-folks in two maritime states in Nigeria. Asian Journal of Information Technology 6 (1), 58 - 64.

Bolorunduro, P.I., Adesehinwa, A.O.K. \& Ayanda, J.O. (2005) Adoption of improved fish preservation technologies in Northwest Nigeria. Tropicultura 23 (3), 117 - 123.

Davies O.A., Davies, R.M. \& Bekibele, D.O. (2008) Fish processing technologies in Rivers State, Nigeria. Journal of Engineering and Applied Sciences 3 (7), 548 - 552.

Garrow, J.S. \& James, W.P.T. (1993) Human Nutrition and Dietetics. $9^{\text {th }}$ Edition. Churchill Livingstone Press, London. p. 847.

George, F.O.A., Ogbolu, A.O., Olaoye, O.J., Obasa, S.O., Idowu, A.A. \& Odulate, D.O. (2014) Fish processing techniques in Nigeria: A case study of Ibeju-Lekki Local Government
Area, Lagos State. American Journal of Food Technology 9 (6), $302-310$.

Inoni, O.E. \& Oyaide, W.J. (2007) Socio-economic analysis of artisanal fishing in the South Agro-Ecological Zone of Delta State, Nigeria. Agricultural Tropical et Subtropical 40 (4), $135-149$.

Kolawole, O.D., Williams, S.B. \& Awujola, A.F. (2010) Indigenous fish processing and preservation practices amongst women in Southwestern Nigeria. Indian Journal of Traditional Knowledge 9 (4), 668 - 672.

Nerquaye-Tetteh, G.A., Dassah, A.L. \& QuashieSam, S.J. (2002) Effect of fuel wood type on the quality of smoked fish - Chrysichthys auratus. Ghana Journal of Agricultural Science 35, 95 - 101.

Odediran, O.F. \& Ojebiyi, W.G. (2017) Awareness and adoption of improved fish processing technologies among fish processors in Lagos State, Nigeria. Research Journal of Agriculture and Environmental Management 6 (3), $046-054$.

Ogunremi, J.B., Sadiq, H.O., Umma, S.B. \& Oshimagye, M.I. (2016) Perception on factors enhancing acceptability of extension agents on service delivery among rural fish farmers in Lagos State, Nigeria. Nigerian Journal of Fisheries and Aquaculture 4 (1), 59 - 62.

Okeowo, T.A., Bolarinwa, J.B. \& Ibrahim, D. (2015) Socioeconomic analysis of artisanal fishing and dominant fish species in Lagoon Waters of Epe and Badagry Areas of Lagos State. International Journal of Research in Agriculture and Forestry 2 (3), 38 - 45.

Okusipe, O.M. (2004) Lagos Lagoon Coastal Profile: Information Database for Planning Theory. Proceeding of the 24th Annual Conference of Environmental Scientific Research Institute (ESRI), San Diego Convention Center, San Diego, California. August 12th, 2004. pp.17. 
Okwu, O.J. \& Acheneje, S. (2011) Socio-economic analysis of fish farming in Makurdi Local Government Area, Benue State, Nigeria. European Journal of Social Sciences 23 (4), $508-514$.

Olaoye, O.J., Ashley-Dejo, S.S., Fakoya, E.O., Ikeweinwe, N.B., Alegbeleye, W.O., Ashaolu, F.O. \& Adelaja, O.A. (2013) Assessment of socio-economic analysis of fish farming in Oyo State, Nigeria. Global Journal of Science Frontier Research: Agriculture and Veterinary 13 (9), $45-55$.

Olaoye, O.J., Ezeri, G.N.O., Akegbejo-Samsons, Y., Awotunde, J.M. \& Ojebiyi, W.G. (2016) Dynamics of the adoption of improved fish farmers in Lagos State, Nigeria. Croatian Journal of Fisheries 74, 56 - 70.

Olaoye, O.J., Idowu, A.A., Omoyinmi, G.A.K., Akintayo, I.A., Odebiyi, O.C. \& Fasina, A.O. (2012) Socio-economic analysis of artisanal fisher folks in Ogun Water-Side Local Government Areas of Ogun State, Nigeria. Global Journal of Science Frontier Research: Agriculture and Biology 12 (4), 9 - 22.

Olaoye, O.J., Odebiyi, O.C. \& Abimbola, O.T. (2015) Occupational hazards and injuries associated with fish processing in Nigeria. Journal of Aquatic Science 3, 1 - 5.

Özçatalbaş, O. (2014) Extension and Innovations: Diffusion of Innovations, Agricultural Extension and Consultancy. (Editors: M. Sayıl, E. Oruç, H. Günal, H. Önen). Vol. 1, Chap. 7, Publisher: Gaziosmanpaşa University Publication No: 2, Tokat, Turkey. $121-136$.
Phillips, O.A., Falana, A.O. \& Olayiwola, M.A. (2012) Assessment of environmental impact on benthic foraminiferal distribution in Lagos Lagoon, Nigeria. Journal of Mining and Geology 48 (1), 68 - 78.

Rogers, E. M. (2003) Diffusion of Innovations. $5^{\text {th }}$ Edn. New York: Free Press, New York. Pp 551.

Sakyi, E.M., Jia, C., Ampofo-Yeboah, A. \& Aglago, A. (2019) Fish Smoking in Ghana: A Review. Journal of FisheriesSciences.com 13 (3), 13 24.

Shettima, B.G., Mohammed S.T., Ghide, A.A. \& Zindam, P.L. (2014) Analysis of socioeconomic factors affecting artisanal fishermen around Lake Alau, Jere Local Government Area of Borno State, Nigeria. Nigerian Journal of Fisheries and Aquaculture 2 (1), $48-53$.

Silva, B.O., Adetunde, O.T., Oluseyi, T.O., Olayinka, K.O. \& Alo, B.I. (2011) Effects of the methods of smoking on the levels of polycyclic aromatic hydrocarbons (PAHs) in some locally consumed fishes in Nigeria. African Journal of Food Science 5 (7), 384 391.

SPSS, (2017) Statistical Package for Social Sciences (SPSS version 20.0). IBM ${ }^{\circledR}$ SPSS $^{\circledR}$ Statistics, SPSS Inc., Chicago, IL, USA.

Wisdom, J.P., Chor, K.H.B., Hoagwood, K.E. \& Horwitz, S.M. (2014) Innovation adoption: A review of theories and constructs. Administration and Policy in Mental Health and Mental Health Services Research 41 (4), 480 - 502. 


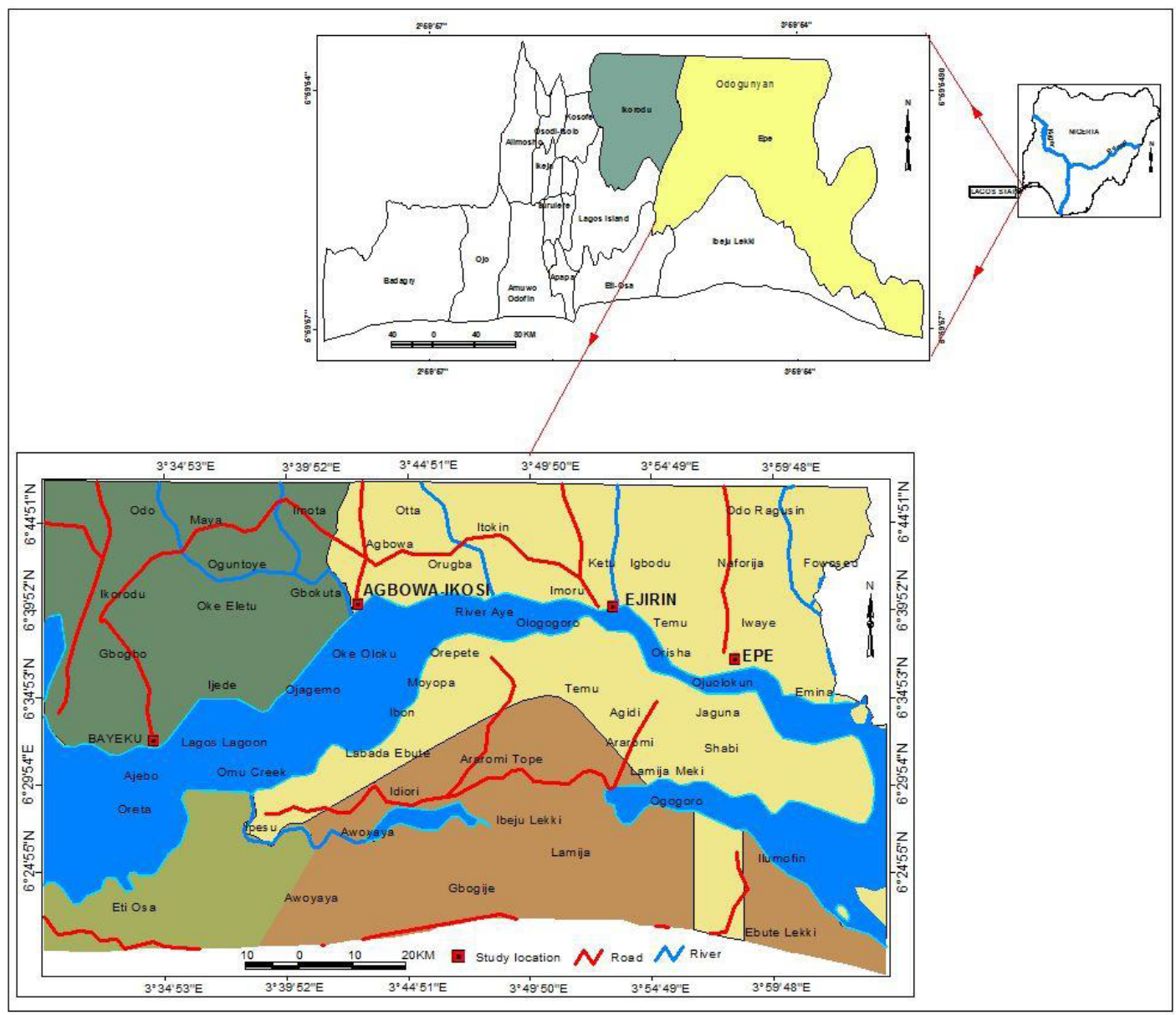

Fig. 1: Map of Lagos Lagoon showing Study Area Source: Field survey, 2018 
TABLE 1

Socio-economic Characteristics of Fish Processors in Lagos Lagoon, Nigeria

\begin{tabular}{|c|c|c|c|}
\hline Characteristics & Frequency & $\begin{array}{c}\text { Percentage } \\
(\%)\end{array}$ & Mean \\
\hline \multicolumn{4}{|l|}{ Gender } \\
\hline Female & 152 & 99.4 & \\
\hline Male & 1 & 0.7 & \\
\hline \multicolumn{4}{|l|}{ Age } \\
\hline$<30$ & 44 & 28.8 & \multirow{5}{*}{$\begin{array}{l}41.7 \\
\text { years }\end{array}$} \\
\hline $31-40$ & 39 & 25.5 & \\
\hline $41-50$ & 36 & 23.5 & \\
\hline $51-60$ & 22 & 14.4 & \\
\hline$>60$ & 12 & 7.8 & \\
\hline
\end{tabular}

\section{Marital status}

Single

Married

$$
1
$$$$
91.5
$$

Separated

140

Widow

$$
9
$$

Highest

Education

Non formal

$$
76
$$$$
49.7
$$

Primary

Secondary

Tertiary

Total household

size (Persons)

$1-5$

$6-10$

$11-15$

$\begin{array}{ccc}66 & 43.1 & 6.2 \\ 78 & 51.0 & \text { per- } \\ 9 & 5.9 & \text { sons }\end{array}$

Years of expe-

rience in fish

smoking

1-10

40

26.1

11-20

21-30

34

$31-40$

21

13

19.6

1.3

$>40$

Membership of Social Organizations*

Fish Processors'

Association

Society

$150 \quad 98.0$

None$$
5
$$

2

29.4

22.2

13.7

8.5

\section{Source: Field survey, 2018; *Multiple Responses}

TABLE 2

Fish Processing Activities and Income Level of Fish Processors in Lagos Lagoon

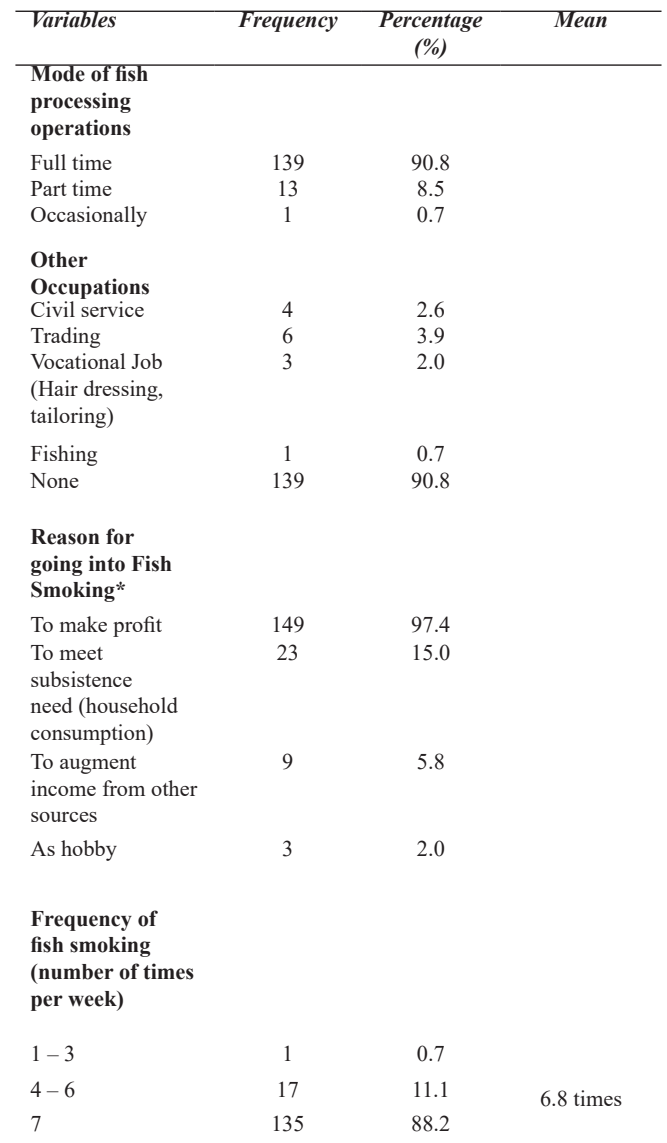

Quantity of fish usually smoked per time (kg)

$\begin{array}{lll}\leq 100 & 73 & 47.7\end{array}$

$\begin{array}{lll}101-200 & 61 & 39.9\end{array}$

$\begin{array}{lll}201-300 & 15 & 9.8\end{array}$

$132.1 \mathrm{~kg}$

$\geq 301$

Estimated

\begin{tabular}{|c|c|c|c|}
\hline$\leq 30,000$ & 49 & 32.0 & \multirow{4}{*}{$\mathrm{N} 48,274.51 \mathrm{~K}$} \\
\hline $31,000-60,000$ & 70 & 45.8 & \\
\hline $61,000-90,000$ & 25 & 16.3 & \\
\hline$\geq 91,000$ & 9 & 5.9 & \\
\hline
\end{tabular}

Monthly Income

(स)

Source: Field survey, 2018; *Multiple Responses 
TABLE 4

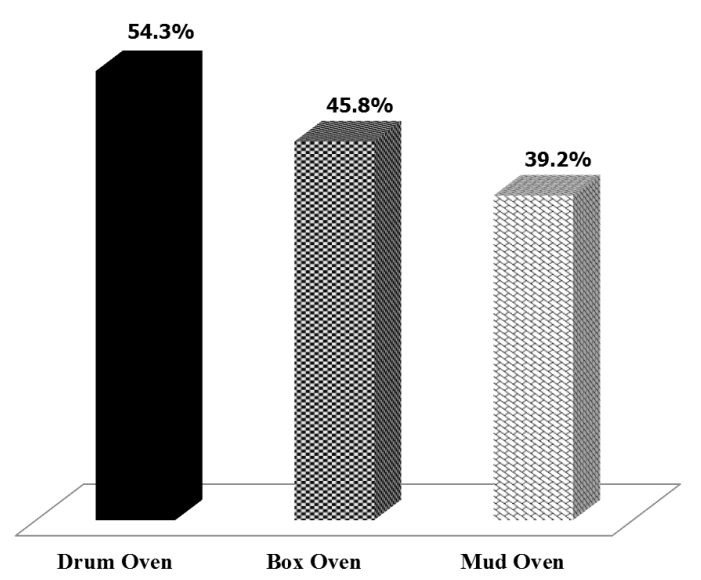

Fig. 2: Types of smoking oven used by the respondents

TABLE 3

Adoption levels of improved traditional smoking oven

\begin{tabular}{|c|c|c|c|c|c|}
\hline \multirow{2}{*}{$\begin{array}{l}\text { Improved } \\
\text { Smoking } \\
\text { Oven }\end{array}$} & \multicolumn{5}{|c|}{ Decision $^{\#}$} \\
\hline & Aware & Trial & Reject & Adopted & $\begin{array}{l}\text { Discon- } \\
\text { tinued }\end{array}$ \\
\hline $\begin{array}{l}\text { Improved } \\
\text { mud oven }\end{array}$ & $52(34.0)$ & $20(38.5)$ & $3(5.8)$ & $17(32.7)$ & $17(32.7)$ \\
\hline $\begin{array}{l}\text { Improved } \\
\text { box oven }\end{array}$ & $24(15.7)$ & $0(0.0)$ & $0(0.0)$ & $0(0.0)$ & $0(0.0)$ \\
\hline $\begin{array}{l}\text { Chorkor } \\
\text { oven }\end{array}$ & $24(15.7)$ & $1(4.2)$ & $0(0.0)$ & $1(4.2)$ & $1(4.2)$ \\
\hline $\begin{array}{l}\text { Smoking } \\
\text { kiln }\end{array}$ & $31(20.3)$ & $0(0.0)$ & $0(0.0)$ & $0(0.0)$ & $0(0.0)$ \\
\hline
\end{tabular}

Source: Field survey, 2018; ${ }^{\# P e r c e n t a g e ~(\%) ~ i n ~}$ Parentheses; $n=153$ for "Aware" while for others, $n=$ "Aware".
Reasons for non-adoption of improved traditional smoking oven $(n=153)$

Constraints Frequency Percentage (\%)

Lack of
awareness
of the
technologies
Lack of
access to the
improved
technologies
Low carrying
capacity due
to limited

to limited number of

101

66.0 fixed wire mesh

Difficulty in turning fish during 48 31.4 smoking

Low relative advantage over traditional smoking 19.0 oven (Longer smoking duration)

Lack of repair and maintenance service High cost of procuring the improved technologies (Smoking kiln)

Lack of interest in the $\quad 3 \quad 2.0$ technologies

Source: Field survey, 2018; *Multiple Responses 
TABLE 5

Awareness of extension services by Fish Processors in Lagos Lagoon

$\begin{array}{lll}\text { Extension service variables } \quad \text { Frequency } & \text { Percentage (\%) }\end{array}$

Awareness of fisheries extension services

Yes

152

99.4

No

1

Sources of awareness

Extension Visits

82

Fellow fish processors

70

46.1

Visitation by fisheries extension agents

Yes

No

71

46.4

Frequency of fishery extension visit*

Fortnightly

3

3.6

Monthly

1

1.2

Quarterly

2

2.4

Twice a year

7

8.5

Not regularly

69

84.2

First contact with extension agents (Year)*

$1990-1999$

3

3.7

$2000-2009$

8

9.8

2010 - 2018 (Present)

Not Certain (Forgotten)

Last contact / visit by extension agents (Year)*

$\begin{array}{lll}1990-1999 & 1 & 1.2 \\ 2000-2009 & 0 & 0.0 \\ 2010-2018 \text { (Present) } & 49 & 59.8 \\ \text { Not Certain (Forgotten) } & 32 & 39.0\end{array}$

Source: Field survey, 2018; *Sample size $=82$ (visited fish processors). 
TABLE 6

Perceived effectiveness of extension services by Fish Processors in Lagos Lagoon

\begin{tabular}{lcr}
\hline Extension service variables & Frequency & Percentag \\
\hline Training on fish processing /smoking & & \\
Yes & 38 & 24.9 \\
No & 115 & 75.1
\end{tabular}

Aspect of fish processing covered by the training $(n=38)$

Use of Improved mud oven

Modern smoking kiln

Improved smoking techniques

Training programmes organized by extension agents $(n=153)$

Yes

No

I don't know

Extension agency $(n=153)$

FADAMA

ACCA

AFAN

I don't know

Frequency of Participation $(n=153)$

Regularly

27

Sometimes

11

29

86

Not at all
42

2

109
110

0.7

71.9

7.2

19.0

56.2

Effectiveness of fisheries extension services $(n=153)$

Excellent 6

Good

Fair 46

Poor 65

Very Poor

13

8.5

Source: Field survey, 2018. 
TABLE 7

Correlation analysis of the socio-economic characteristics, fish smoking activities and adoption of improved smoking ovens

\begin{tabular}{|c|c|c|c|c|c|c|}
\hline Variables & $\begin{array}{l}\text { Mode of fish } \\
\text { processing } \\
\text { operations }\end{array}$ & $\begin{array}{l}\text { Frequency } \\
\text { of fish } \\
\text { smoking }\end{array}$ & $\begin{array}{l}\text { Quantity } \\
\text { of fish } \\
\text { smoked }\end{array}$ & $\begin{array}{l}\text { Income } \\
\text { level }\end{array}$ & $\begin{array}{l}\text { Smoking } \\
\text { oven used }\end{array}$ & $\begin{array}{l}\text { Adoption of } \\
\text { improved } \\
\text { smoking oven }\end{array}$ \\
\hline Age & 0.081 & $-0.274^{* *}$ & -0.037 & -0.083 & -0.059 & $-0.322^{* *}$ \\
\hline Gender & $0.230^{* *}$ & $-0.303^{* *}$ & -0.008 & $0.175^{*}$ & 0.011 & 0.030 \\
\hline $\begin{array}{l}\text { Marital } \\
\text { status }\end{array}$ & 0.051 & $-0.173^{*}$ & -0.049 & -0.079 & 0.059 & $-0.221^{* *}$ \\
\hline $\begin{array}{l}\text { Education } \\
\text { level }\end{array}$ & $0.254^{* *}$ & -0.025 & $-0.166^{*}$ & $-0.161^{*}$ & 0.052 & 0.125 \\
\hline $\begin{array}{l}\text { Household } \\
\text { size }\end{array}$ & $0.206^{*}$ & $-0.184^{*}$ & -0.148 & -0.069 & 0.142 & -0.148 \\
\hline $\begin{array}{l}\text { Fish } \\
\text { smoking } \\
\text { experience }\end{array}$ & 0.079 & $-0.292^{* *}$ & 0.032 & -0.002 & -0.040 & $-0.204^{*}$ \\
\hline
\end{tabular}


TABLE 8

Estimates of regression analysis for the determinant of adoption of improved fish smoking oven

\begin{tabular}{|c|c|c|c|c|c|}
\hline & \multirow[t]{2}{*}{ Parameters } & \multicolumn{2}{|c|}{$\begin{array}{l}\text { Unstandardized } \\
\text { Coefficients }\end{array}$} & \multirow{2}{*}{$\begin{array}{c}\begin{array}{c}\text { Standardized } \\
\text { Coefficients }\end{array} \\
\beta\end{array}$} & \multirow[t]{2}{*}{ t-ratio } \\
\hline & & $\beta$ & $\begin{array}{l}\text { Std. } \\
\text { Error }\end{array}$ & & \\
\hline Constant & $\beta_{0}$ & 2.578 & 0.491 & & $5.250 * * *$ \\
\hline Age $\left(X_{1}\right)$ & $\beta_{1}$ & -0.015 & 0.004 & -0.658 & $-3.847 * * *$ \\
\hline Gender $\left(\mathrm{X}_{2}\right)$ & $\beta_{2}$ & -0.212 & 0.293 & -0.053 & -0.724 \\
\hline Marital status $\left(\mathrm{X}_{3}\right)$ & $\beta_{3}$ & -0.032 & 0.035 & -0.076 & -0.911 \\
\hline Education level $\left(\mathrm{X}_{4}\right)$ & $\beta_{4}$ & 0.017 & 0.030 & 0.042 & 0.552 \\
\hline Household size $\left(\mathrm{X}_{5}\right)$ & $\beta_{5}$ & -0.001 & 0.010 & -0.008 & -0.112 \\
\hline $\begin{array}{l}\text { Fish smoking } \\
\text { experience }\left(\mathrm{X}_{6}\right)\end{array}$ & $\beta_{6}$ & 0.010 & 0.004 & 0.444 & $2.621 * *$ \\
\hline $\begin{array}{l}\text { Frequency of fish } \\
\text { smoking }\left(X_{7}\right)\end{array}$ & $\beta_{7}$ & -0.071 & 0.034 & -0.163 & $-2.076^{*}$ \\
\hline $\begin{array}{l}\text { Quantity of fish smoked } \\
\left(\mathrm{X}_{8}\right)\end{array}$ & $\beta_{8}$ & 0.000 & 0.000 & 0.099 & 1.360 \\
\hline $\begin{array}{l}\text { Smoking oven used } \\
\left(X_{q}\right)\end{array}$ & $\beta_{9}$ & -0.001 & 0.029 & -0.002 & -0.029 \\
\hline $\begin{array}{l}\text { Extension agent visit } \\
\left(\mathrm{X}_{10}\right)\end{array}$ & $\beta_{10}$ & 0.220 & 0.068 & 0.338 & $3.250 * * *$ \\
\hline $\begin{array}{l}\text { Training on fish } \\
\text { smoking }\left(X_{11}\right)\end{array}$ & $\beta_{11}$ & 0.182 & 0.051 & 0.285 & $3.586^{* * *}$ \\
\hline $\begin{array}{l}\text { Perceived effectiveness } \\
\text { of extension services } \\
\left(\mathrm{X}_{12}\right)\end{array}$ & $\beta_{12}$ & -0.077 & 0.036 & -0.232 & $-2.163^{*}$ \\
\hline
\end{tabular}

Source: Field survey, 2018; $R=0.605 ; R$ Square $\left(R^{2}\right)=0.366 ;$ Adjusted $R^{2}=0.311 ;$ F-value $=$ $6.638 @ P<0.001 ; *=P<0.05 ; * * P<0.01 ; * * * P<0.001$ 